\title{
SEGURANÇA E USO DA FORÇA NO CONTEXTO DA OTAN PÓS-GUERRA FRIA
}

\author{
Juliana Lyra Viggiano Barroso
}

\begin{abstract}
RESUMO
A redefinição das relações de força no sistema internacional, decorrente do esgotamento do arranjo bipolar, teve implicações significativas para a Aliança Atlântica. Pautada por um modelo de defesa coletiva que privilegiava as variáveis geoestratégicas, a Aliança não dava conta dos imperativos de segurança da nova configuração sistêmica. Ao assimilar essa incompatibilidade, os membros da Aliança redefiniram seu plano estratégico em 1991 e atribuíram às possíveis instabilidades econômicas, políticas e sociais provenientes, em especial, dos países do Leste Europeu, seu principal foco de ameaça. Em 1999, por meio da prática da intervenção e do maior comprometimento norte-americano a partir de meados da década, a OTAN lapida seus critérios ao harmonizar o uso da força e a leitura das ameaças de segurança em seus preceitos normativos.
\end{abstract}

PALAVRAS-CHAVE: segurança; OTAN; regimes internacionais.

\section{INTRODUÇÃO}

Ainda que não compartilhada por todas as correntes de pensamento internacionalista, a proliferação dos estudos na área de organizações internacionais com o fim da Guerra Fria demonstra certo otimismo por parte dos pesquisadores e dos formuladores de política em geral acerca do papel mais atuante a ser ocupado pelos arranjos multilaterais e pelos regimes na coordenação dos assuntos externos dos estados. Dessa percepção positiva não escaparam também as organizações responsáveis pelas questões de guerra e de paz no sistema, cujo sucesso do Conselho de Segurança da Organização das Nações Unidas em mediar os esforços dos países membros para a investida militar na Guerra do Golfo serviram de motivação e exemplo.

As transformações sistêmicas alçaram temas de política soft, tais como aspectos econômicos ${ }^{1}$, de direitos humanos e de meio ambiente, a posições de destaque na agenda internacional, ao contrário do privilégio concedido ao debate das questões estratégico-militares ${ }^{2}$. $\mathrm{O}$ viés essencialmente polarizado da agenda militarista dominante nos

\footnotetext{
${ }^{1}$ As questões econômicas são tratadas por alguns autores como temas intermediários.

2 A emergência dos temas de direitos humanos no período posterior à Guerra Fria, na realidade, ganharam maior visi-
}

anos da Guerra Fria inviabilizava a elaboração de uma pauta comum de segurança a todos os estados. Contudo, a promoção dos temas de terceira geração como também se denominam os assuntos de política soft permearam todas as esferas do discurso internacional, inclusive os elementos relacionados à segurança. A partir de então, diluem-se ainda mais as fronteiras de separação entre as grandes áreas englobadas pelas relações internacionais ${ }^{3}$. Em outras palavras, observa-se a crescente complexidade dos processos de interdependência entre esses diversos temas na política externa dos estados ${ }^{4}$. O conceito de segurança adquire natureza multidimensional, ou

bilidade. Villa aventa a possibilidade de se pensar a diplomacia dos direitos humanos na era Carter como "a primeira fissura relevante do quadro conceitual de premissas realistas na Guerra Fria" (VILLA, 1999, p. 106). No entanto, se momentos de desanuviamento das tensões durante o período bipolar permitiram o surgimento embrionário de concepções menos rígidas de segurança, foi a partir dos anos 1990 que "novos" temas tiveram de fato a oportunidade de aflorar e ganhar espaço na agenda de política internacional.

3 Para aprofundar-se na relação entre segurança e direitos humanos no período posterior à Guerra Fria, consultar Patriota (1998), em especial o capítulo 4, e Rodrigues (2000).

4 Acompanha a intensificação da interdependência temática a maior interconexão entre os níveis de análise do sistema internacional. 
seja, a segurança "já não pode mais ser visada em termos de acréscimo de poder" (VILLA, 1999, p. $177)^{5}$.

Reconhecer a multidimensionalidade dos assuntos de segurança suscita problemas relevantes para a Organização do Tratado do Atlântico Norte (OTAN), cuja natureza encontra-se intimamente relacionada ao mecanismo de segurança coletiva que comporta em suas diretrizes normativas. A questão tratava-se de adaptar seu principal instrumento de ação, o uso dos recursos militares para autodefesa, aos desafios impostos pela natureza multifacetada dos desafios de segurança identificados com o mundo pós-Guerra Fria.

Com esse espírito, a OTAN reavalia suas funções e seu papel no contexto europeu em conformidade com essa leitura heterodoxa da segurança e dos eventuais elementos perturbadores da paz. As primeiras mudanças significativas de caráter normativo datam de 1991, ano em que seus membros ratificaram os novos objetivos estratégicos da aliança. A partir da aceitação formal do documento intitulado Conceito Estratégico da Aliança, a OTAN passa a ser regida por um autêntico conjunto de normas, caracterizando uma alteração em seu regime de segurança. As cláusulas do Conceito apresentam uma imprecisão entre as possibilidades previstas para o uso de força militar e a concepção de segurança pautada na promoção e no desenvolvimento dos valores democrático-liberais. Essa dificuldade normativa é sanada pela Aliança Atlântica com a revisão do Conceito Estratégico em 1999, ao inserir em suas cláusulas constitutivas a viabilidade tanto de agir quanto de não agir, em termos defensivos, para a preservação de um ambiente seguro na Europa.

A OTAN redefine seu papel ao associar diretamente a noção de segurança à estabilidade regio-

\footnotetext{
5 No que diz respeito ao foco dessa pesquisa, no entanto, não cabe se trabalhar com o conceito de segurança global multidimensional desenvolvido pelo autor (VILLA, 1999). A singularidade da segurança global multidimensional reside na impossibilidade de admitir a guerra como meio de solução de conflitos, nem mesmo como ultima ratio (idem, p. 177). A intervenção humanitária em resgate àqueles que sofrem abusos ou violações dos direitos humanos, como foi o caso da Guerra da Bósnia e do Cosovo, contraria em princípio a conceituação. O empréstimo do termo multidimensional, contudo, convém pela precisão ao denotar as variadas origens dos temas que passam a permear o conceito de segurança.
}

nal, derivada da consolidação dos valores democráticos e liberais no continente, sobretudo com referência aos direitos humanos. A institucionalização normativa da democracia liberal nos remete ao interessante debate do papel das idéias enquanto variáveis explicativas para a ação externa dos estados. Se, por um lado, não há muita controvérsia acerca da importância da questão ideológica como causa motivadora do agir na política, por outro, as conseqüências esperadas das idéias enquanto causas diferem nas diversas perspectivas teóricas.

A abordagem liberal apresenta as crenças ou expectativas como modeladores das preferências tradicionais. Nesse sentido, inclui critérios do mundo das idéias aos cálculos de política externa dos estados. A institucionalização dos valores da democracia liberal nas diretrizes normativas da OTAN, na realidade, reflete a incorporação, ao menos parcial, desses mesmos valores pelos países membros em suas percepções do que devem ser as relações interestatais. Da mesma forma, a maleabilidade assumida pelas cláusulas do Conceito em 1999, acerca da interferência armada da organização em favor da manutenção da estabilidade européia, conquistada pela perfeita observação desses valores, evidencia a fragilidade do processo no âmbito do uso da máquina militar no cenário internacional.

Como se poderá verificar ao longo da última parte desse trabalho, as idéias institucionalizadas pela OTAN moldam as preferências de acordo com as circunstâncias. A heterogeneidade com que os eventos afetam os diferentes atores envolvidos nas decisões demonstra a incompleta internalização dos valores democrático-liberais pela opinião pública e pelos formuladores de política acerca da legitimidade de se agir exclusivamente em nome das idéias ${ }^{6}$. A participação ativa da aliança no conflito da Bósnia (1992-1995) e do Cosovo (1999) instiga a pensar o caminho futuro para o qual se movimenta a relação entre valores, preferências e organizações internacionais.

Em contraste com a guerra no Cosovo, o conflito da Bósnia sensibilizou a opinião pública de forma favorável à intervenção das potências ocidentais somente depois de três anos de lutas

\footnotetext{
6 Para uma leitura sobre o papel das idéias nas relações internacionais a partir da perspectiva institucionalista, ver Goldestein e Keohane (1993).
} 
caracterizados, desde o seu início, pela política de limpeza étnica. Essa reação tardia deve-se, principalmente, aos problemas internos que os Estados Unidos enfrentavam e à incapacidade dos países europeus de encontrarem consenso acerca da estratégia de uma eventual intervenção. A perspectiva de repetição do desastre bósnio de massiva violação dos direitos humanos no Cosovo mobilizou a opinião pública com maior rapidez. Embora o conflito balcânico do final da década de 1990 possuísse um caráter geopolítico ausente na Bósnia, a justificativa de intervenção em ambos os casos foi fortemente atribuída à necessidade de defesa dos direitos humanos ${ }^{7}$.

As análises dos conflitos na Europa corroboram a proposta da deficiência dos valores como motivador central para a ação externa dos estados, via instituição, uma vez que tanto na Bósnia quanto no Cosovo o estímulo dos líderes foi fundamental para a aceitação pública das investidas militares. Contudo, não parece haver interesses paralelos na intervenção bósnia além daqueles explicitados nos discursos humanitários. Se essa relação não pode ser estabelecida para o caso do segundo conflito, certamente as ameaças estratégicas não constituíram a base das explicações públicas dos governos dos países membros, nem pelos representantes da OTAN, para o envolvimento na ação armada. Em suma, foi exatamente a crença na necessidade de manter a ordem de acordo com os preceitos democráticoliberais que viabilizou, em último plano, a estratégia intervencionista da Aliança Atlântica.

Se as idéias no contexto da OTAN ainda não estão suficientemente internalizadas a ponto de permitir a demanda pública de ação intervencionista exclusivamente calcada nos valores, os exemplos mencionados tornam plausível especular um movimento a favor da completa legitimação dos atores políticos, no seu sentido mais amplo, e de ações do Estado motivadas pelas crenças em primeiro plano ${ }^{8}$.

\footnotetext{
7 Para uma análise mais detalhada dos conflitos mencionados e do papel da OTAN nesse contexto, ver Viggiano (2005).

8 Essa leitura aproxima-se muito da análise construtivista realizada por Messari no tocante às instituições internacionais de segurança. Para o autor, essas instituições constituir-se-iam no novo locus de identidade, tornando as intervenções humanitárias em ações legítimas (MESSARI, 2003, p. 171-195).
}

O presente artigo divide-se em três partes, além da introdução. A seção seguinte analisará o documento de formação da OTAN, o Tratado de Washington, com o objetivo de apresentar, na terceira seção, as diferenças fundamentais encontradas nas cláusulas do Conceito Estratégico da Aliança, implementado pela organização em 1991, referentes ao uso da força. A última parte dedica-se a estudar com cuidado o documento ratificado em 1999, que vem substituir o Conceito Estratégico do imediato pós-Guerra Fria, com o intuito de identificar maior consistência em seus preceitos normativos frente aos estabelecidos em 1991, refletindo o amadurecimento do regime ao longo da década de 1990 .

\section{A ORIGEM DAALIANÇA:A IMPORTÂNCIA DASEGURANÇACOLETIVA}

A Organização do Tratado do Atlântico Norte nasce em 4 de abril de 1949 com o Tratado de Washington, e entra em vigor em 24 de agosto do mesmo ano após o depósito da ratificação de todos os países signatários. O documento original é composto por 14 artigos que descrevem os objetivos e o alcance da aliança no contexto da Guerra Fria.

$\mathrm{O}$ surgimento da OTAN responde à ameaça imposta pelo sistema bipolar aos interesses e ao conjunto de valores que subsidiam a visão de mundo Ocidental. Embora seu texto não faça menção explícita à União Soviética, a organização catalisou o desejo de unir a Europa e os Estados Unidos em uma única frente contra o desafio comunista. A Europa era vulnerável devido a sua proximidade geográfica do território soviético e, ao mesmo tempo, era considerada a área de influência mais importante para os Estados Unidos. A concretização, portanto, de um organismo fundamentado no princípio de defesa coletiva firmava o comprometimento americano com a segurança de seus aliados europeus. Além de poder contar com um aparato militar tradicional, a presença direta dos EUA oferecida pela aliança destacava-se, primordialmente, pelo "guarda-chuva" nuclear disponibilizado por estes, estabilizando a balança de poder na região ${ }^{9}$.

\footnotetext{
9 Em fins dos anos 1960, contudo, um confronto militar entre uma potência européia e a URSS tornara-se pouco provável. O alto grau tecnológico que alcançaram os dispositivos nucleares e a paridade quantitativa do arsenal na maior parte do período que se segue desencadeou uma situ-
} 
A intenção de arregimentar um bloco homogêneo em suas expectativas, liderado politicamente pelos Estados Unidos, aparece de duas formas no Tratado. Já no artigo 2 afirma-se que "as partes contribuirão para o desenvolvimento de relações internacionais pacíficas e amigáveis por meio do fortalecimento de suas instituições livres, da melhor compreensão dos princípios sobre os quais essas instituições estão fundamentadas e promover condições para estabilidade e o bem-estar" $\left(\text { NATO, 1949, art. } 2^{\circ}\right)^{10}$. Dessa maneira, "a OTAN desenvolveu-se como uma parceria entre estruturas governamentais democráticas similares onde existem e são verbalizadas diferenças, muito embora se reconheça a liderança incontestável de um dos membros" (FRANÇA, 2004, p. 102). O modelo de estruturação das relações sugerido pelo texto, portanto, estimula a criação de elementos políticos e sociais de identidade comuns e laços de interdependência econômica. Nessa direção, o texto de 1949 , na continuação do artigo $2^{\circ}$, tira o foco de sua atenção das questões exclusivamente militares para estabelecer a responsabilidade dos países signatários em procurar "eliminar conflitos de suas políticas econômicas internacionais e [encorajar] a colaboração econômica entre algumas ou todas as partes" (NATO, 1949, art. $2^{\circ}$ ), com o propósito de extinguir, definitivamente, estes países de qualquer influência do Leste.

A segunda questão elaborada com o objetivo de fortalecer a integração dos países livres referese aos arranjos de segurança propriamente, previstos pelo Tratado de Washington. De modo a cumprir o objetivo, textualizado na parte introdutória do documento, de "salvaguardar a liberdade, a herança comum e a civilização de seus povos, baseados nos princípios de democracia,

ação de paralisia garantida "por complexas equações de equilíbrio nas armas, [sendo] a sigla americana que exprime [tal] impasse [...] sintomaticamente [chamado] MAD (mutual assured destruction)" (FONSECA JÚNIOR., 1995, p. 132). O reconhecimento da MAD no caso de um enfrentamento sem intermediários entre as superpotências minimizava a possibilidade de violação territorial dos países da Europa Ocidental, uma vez que o mecanismo de defesa coletiva da OTAN garantiria o envolvimento dos Estados Unidos em situações que ameaçassem a segurança de um dos países signatários.

10 As citações referentes ao Tratado de Washington foram retiradas da versão portuguesa do documento. Pequenas alterações foram realizadas somente com o intuito de adequar o linguajar. liberdade individual e a regra da lei" (idem), o artigo $3^{\circ}$ anuncia o direito dos membros da aliança em "manter e desenvolver sua capacidade individual e coletiva de resistir a ataques armados" por meio de "continuada e efetiva auto e mútua ajuda" $\left(\right.$ idem, art. $\left.3^{\circ}\right)$. Associado a esta dimensão do direito de autodeterminação, o famoso e comentado artigo $5^{\circ}$ define a OTAN enquanto um organismo de segurança e defesa coletiva ${ }^{11}$. A referida cláusula estipula: "um ataque armado contra uma ou mais das Partes na Europa ou na América do Norte será considerado um ataque a todos e, conseqüentemente, as Partes concordam que, se um tal ataque armado se verificar, cada um [dos estados membros] [...] prestará assistência à Parte, ou Partes assim atacadas, praticando sem demora, individualmente e de acordo com as restantes partes, a ação que julgarem necessária, inclusive o emprego da força armada, para restaurar e garantir a segurança na região do Atlântico Norte" (idem, art. $5^{\circ}$ ).

Um mecanismo de defesa coletiva, também denominada de defesa territorial, opera como uma salvaguarda à inviolabilidade territorial dos estados que dele se beneficiam, ao garantir "a proteção aos seus membros contra agressões ou coerção" (YOST, 1998, p. 135). A presença da OTAN no contexto de uma Europa Ocidental debilitada ao fim de seis anos de guerra e, portanto, vulnerável às investidas expansionistas soviéticas oferecia um lastro institucional para a participação efetiva dos EUA nos assuntos de segurança do

11 Os termos segurança coletiva e defesa coletiva não possuem significado homônimo, alerta Yost. Segurança coletiva remete à idéia kantiana ou wilsoniana de estabelecer uma "associação geral de nações, a ser constituída através de convênios específicos, tendo em vista proporcionar garantias mútuas de independência política e integridade territorial tanto aos grandes quanto aos pequenos estados" (NYE JUNIOR, 2000, p. 103). O termo ainda responde a uma segunda acepção, derivada da aspiração fundamental da segurança coletiva, pautada "na construção de um senso de solidariedade e responsabilidades compartilhadas perene em questões relativas à paz e segurança internacionais" (YOST, 1998, p. 137). Embora a OTAN não tenha por objetivo criar um sistema coletivista unicamente calçado nessa visão, pois a "atuação prática em favor da segurança coletiva, atualmente, em geral, consiste em intervenções multilaterais", por muitos anos a aliança tem encampado algumas das idéias dessa tradição. Entre elas "transparência com relação às capacidades e planos militares, democratização (incluindo o controle militar, civil e democrático) e a proposição de que 'segurança é indivisível"' (idem, p. 138). 
continente, os únicos capazes de equilibrar a balança de poder na região ${ }^{12}$.

No que diz respeito especificamente aos interesses norte-americanos, por mais de 40 anos, seus líderes "aceitavam, em geral, que a presença dos Estados Unidos na Europa desempenhava um papel construtivo na estabilização do Oeste europeu [...] e esperavam prevenir o renascimento de conflitos internos" entre tais países (SLOAN, 1995, p. 219). Assim, a OTAN contribuía para fortalecer a unidade e a segurança nessa parte do continente e proporcionava uma estrutura organizacional que possibilitava à superpotência americana engajar-se ativamente na sua reconstrução política e econômica e introduzir novos padrões de cooperação entre antigos adversários (SLOAN, 1995).

Nas décadas seguintes à formação da aliança, a intensificação da disputa entre os dois pólos que compunham o sistema internacional no período da Guerra Fria evolui para uma situação de détente que paralisou o funcionamento da OTAN enquanto organismo de defesa coletiva. A certeza de mutual assured destruction demandava cautela, e impediu qualquer ação agressiva que incitasse a participação das superpotências em conflitos armados diretos. Graças ao mecanismo de defesa coletiva da OTAN, os territórios dos países europeus, resguardados sob o guarda-chuva norteamericano providenciado pela aliança, não sofreram nenhuma violação. Portanto, a organização cumpriu um papel mais simbólico do que efetivo ao longo deste período da história. De maneira alguma, contudo, esta última afirmação questiona a eficácia do organismo enquanto instrumento de uma política de contenção ${ }^{13}$. Na realidade, sua inoperância mais atesta do que desmente a eficácia do método.

12 A Aliança do Atlântico Norte também cumpria outro papel fundamental: garantir a estabilidade na Europa. Recém-liberta do pesadelo de duas devastadoras guerras, a organização amenizava os receios europeus de uma potencial investida expansionista alemã.

13 A aliança serviu, ao mesmo tempo, aos objetivos ofensivos e defensivos de uma política de contenção. Enquanto a idéia de defesa coletiva ambicionava "uma política mais limitada de contenção da União Soviética", a proposta mais ampla de segurança coletiva cuidava de conter a disseminação do conteúdo ideológico da disputa, o comunismo (NYE JUNIOR, 2000, p. 137).
A mudança verificada na lógica do sistema internacional com o fim do regime comunista soviético tornou questionável a existência da OTAN. Ao longo da segunda metade do século XX até 1989, a organização tinha dois papéis centrais e de consistente justificativa. Em primeiro lugar, a aliança intermediava a presença dos Estados Unidos na região, necessária como contrapeso ao poderio militar soviético (DUFFIELD, 19941995). Diretamente associado ao problema da balança de poder, o segundo motivo recai no enfrentamento ideológico que sustentava a dinâmica do sistema bipolar. Em um mundo pautado pela disputa armamentista e pelo interesse de expansão de dois modelos de organização política, econômica e social contrapostos, manter uma instituição nos moldes da OTAN na mais importante área de influência dos EUA não gerava nenhum tipo de alarmante controvérsia entre os setores da política doméstica, quer nos países europeus partícipes, quer nos Estados Unidos. Contudo, em apenas dois anos, o contexto que subsidiava sua raison d'etre desapareceu: em 9 de novembro de 1989 caiu o Muro de Berlim, onze meses depois a Alemanha reunificou-se; em $1^{\circ}$ de abril de 1991 o Pacto de Varsóvia rompeu-se, seguido, em 25 de dezembro do mesmo ano, pelo desmembramento da União Soviética.

A erosão do sistema que coordenava as ações dos estados na Guerra Fria e, com ele, as ameaças patentes à segurança das fronteiras, dissipouse. A insurgente ordem internacional propõe uma distinção nebulosa entre a clássica dicotomia amigo/inimigo, variável central pela determinação do perfil das relações interestatais no período precedente, sobretudo das questões de segurança internacional. A falta de clareza para definir o binômio decorre da falência do modelo de segurança tradicional, cuja formulação apoiava-se em preocupações de natureza geopolítica. Ausente o "perigo vermelho", e com ele o enfrentamento ideológico e sua ambição expansionista, potencial motivador de um conflito armado entre os dois mundos, o elemento territorial perde parcialmente sua importância para os Estados Unidos e os principais países europeus no contexto internacional.

Se a capacidade bélica russa, maior herdeira do legado militar soviético, ainda assombra os países vizinhos dado seu potencial destrutivo, a partícula motivadora subjacente a manipulação com propósitos ofensivos de um aparato de tal 
magnitude em uma investida contra os países europeus dissipa-se. Permanecem os meios para realizar a ação, porém desvanece o elemento capaz de dar sentido lógico à ação, de justificá-la. Devido a esta perda da essência do ato de agressão, o problema da violação territorial perde significativamente sua importância ${ }^{14} 15$.

Ao esvaecer-se o padrão de relacionamento entre estados pautado na noção amigo/inimigo, a OTAN, enquanto uma organização de segurança fundamentalmente voltada para o exercício da defesa territorial, sente a necessidade de reavaliar seus objetivos. Essa idéia reflete-se nas palavras do Secretário Geral, Manfred Wörner 16: "a Aliança Atlântica [...] gerou aspirações. Esses são os resultados, quando falamos de conseqüências: um

\footnotetext{
14 Contudo, não há um desinteresse completo pelas questões territoriais, apesar de assumirem uma posição marginal no contexto da aliança. O processo de transição institucional iniciado na Rússia no início da década de 1990 gera incertezas quanto ao rumo futuro do país.

15 Nem todos os autores concordam com essa perspectiva de desenvolvimento do cenário internacional. Mearsheimer, em seu artigo Back to the Future:Instability in Europe After the Cold War, exprime a opinião de que, ao desvencilhar-se completamente da estrutura bipolar herdada da Guerra Fria e se mover para um sistema multipolar, os Estados europeus, devido à maior instabilidade do sistema então configurado, arriscam-se a entrar em um período de anarquia, onde as alianças sofrerão alternâncias constantes e as instituições serão de pouca validade. Nesse contexto, o retorno às opções militares seria uma inevitável conseqüência (MEARSHEIMER, 1990). A aposta dessa pesquisa em uma visão mais voltada para o desenvolvimento político da Organização do Tratado do Atlântico Norte a partir de 1991 reflete a própria percepção da aliança, apresentada desde o artigo introdutório do Conceito Estratégico do final da década analisado a seguir.
}

16 Questiona-se, no entanto, por que não o desativar, visto que se tratava de um organismo anacrônico para as dificuldades a serem enfrentadas no novo sistema em construção. A resposta recai nos interesses norte-americanos e europeus em sua continuidade. A cooperação via OTAN é a porta de entrada "para os EUA influenciarem nas questões de segurança européia e dividirem os gastos militares e financeiros de policiar a segurança internacional e do continente de forma mais eqüitativa com seus aliados mais próximos" (SLOAN, 1995, p. 218). Ademais, seu incomparável poderio militar concede-lhes posição de destaque nas negociações laterais que ocorrem antes e durante os processos decisórios. E, embora os valores liberais e instituições democráticas já se encontrem arraigadas nas atividades políticas e econômicas de seus membros, a partir dos eventos que ocorrem logo após a queda do Muro de Berlim, é plausível pensar que os Estados Unidos encarem a sobre- mundo em imensa transição, o fracasso do comunismo, a demanda por novas estruturas de paz baseadas nos preceitos da Aliança de liberdade, dignidade humana e auto-determinação [...]. O futuro da OTAN é determinado pelo contexto com que nos deparamos: primeiramente, providenciar uma estrutura de estabilidade e coesão em um momento de grandes mudanças: No entanto, e tão importante quanto, ser um instrumento dessa mudança - encorajá-la e oferecê-la sólidos pilares nos quais possa apoiar-se. [...] E essa Aliança consiste na única instituição ocidental capaz de administrar a estratégia adequada requerida. Propostas políticas, econômicas, militares e de direitos humanos não podem ser trabalhadas isoladamente" (WÖRNER, 1989).

Com esse espírito, a Aliança Atlântica começa a traçar os rumos do caminho a percorrer nessa próxima etapa da história em que o mundo então entrava.

\section{O CONCEITO ESTRATÉGICO DE 1991: O INÍCIO DA MUDANÇA}

O Conceito Estratégico da Aliança resulta do encontro entre chefes de Estado dos países da OTAN na cidade de Londres em julho de 1990, apresentado em sua versão final em 8 de novembro de 1991. Ao reconhecerem no artigo introdutório o impacto das transformações em

vivência da aliança como uma ótima oportunidade para disseminação destes mesmos valores para os países do exbloco comunista. Os termos do novo regime de segurança da OTAN aprovado pelos Estados-membros em 1991, analisados a seguir, corroboram para validar tal hipótese. No tocante à perspectiva dos países europeus, a existência da OTAN ainda era sinônimo de estabilidade na balança de poder da região. Assistiu-se ao término do comunismo soviético, porém, reforçando argumento a pouco mencionado, a capacidade russa no que se refere a armamentos mantém-se desproporcionalmente superior ao arsenal dos países europeus, em particular quando o assunto são armas nucleares. A prudência, portanto, recomenda aos países europeus não desistirem da organização de defesa regional, já que a OTAN constitui o meio pelo qual os EUA atuam no continente, não só, mas também, para contrabalançar poder. Vale salientar que hostilidades advindas de uma Rússia dependente do capital estrangeiro para realizar uma série de transformações estruturais necessárias para sua reinserção no cenário internacional, contudo, são pouco prováveis no curto prazo (EYAL, 1997). Esse é o motivo pelo qual o cumprimento da função de balança de poder perdeu relevância, mas não foi banido do texto do Conceito Estratégico da aliança, documento que guiará os passos da instituição a partir de 1991, data de sua oficialização. 
processo na Europa na definição dos seus objetivos futuros, os representantes de governo optaram por uma revisão estratégica dos princípios da aliança, cujos resultados estão registrados nos 59 pontos em que se divide o documento.

Ao especificar o novo contexto estratégico em que a organização se encontrava, o artigo $5^{\circ}$ observa que "[a] ameaça monolítica, massiva e potencialmente imediata que constituía a preocupação central da Aliança em seus primeiros 40 anos desapareceu" (NATO, 1991, art. $5^{\circ}$ ). Não obstante, completam os pontos 12 e 13, "[...] [mesmo] em uma relação não-conflitiva e cooperativa, a capacidade e o potencial de desenvolvimento militar soviéticos, ainda constitui o fator mais significativo com o qual a aliança deve lidar ao manter a balança estratégica na Europa [...]" (idem, art. 12) e reafirma sua posição de que "[qualquer] ataque armado ao território dos aliados, independente da procedência, será respondido de acordo com os artigos $5^{\circ}$ e $6^{\circ}$ do Tratado de Washington [...]" (idem, art. 13).

Ao evocar o artigo $5^{\circ}$ do Tratado do Atlântico Norte, o artigo 12 do Conceito Estratégico demonstra cuidado com a dimensão geopolítica que caracteriza o conceito tradicional de segurança ao reafirmar a função de defesa coletiva do organismo. No entanto, o artigo 14 não deixa dúvidas quanto ao foco estratégico estabelecido pelo documento: "[...] o novo ambiente não muda o propósito ou as funções de segurança da aliança, mas, ao contrário, sublinha sua contínua validade [...] por outro lado, a mudança no ambiente oferece novas oportunidades para a aliança enquadrar sua estratégia em uma visão mais ampla de segurança" (NATO, 1991, art. 12; sem grifo no original).

A percepção mais abrangente das noções de segurança responde aos desígnios da nova conformação do sistema internacional. Manfred Wörner, Secretário Geral da OTAN em 1990, observa que a fase de mudanças históricas vivenciada no início da década oferece a oportunidade para a Aliança Atlântica concretizar seus desejos "de uma Europa livre e unificada fundamentada em uma ordem pacífica, segura e duradoura". Nesse contexto, importa especialmente o conteúdo substantivo responsável pelo estabelecimento de tal ordem: "direitos humanos e livre escolha para todos os cidadãos, igualdade perante a lei, abertura das fronteiras, autodeterminação, democracia e a proteção dos direitos das minorias" (WÖRNER,
1990). Com base nessa visão de mundo, a Aliança reestrutura seu projeto de segurança coletiva em 1991 e abre caminhos para um modelo de regime original.

Com o fim da Guerra Fria, mais precisamente, com a dissolução do socialismo no Leste Europeu, a percepção de segurança, pautada exclusivamente nas preocupações de cunho geopolítico, tornava-se pouco convincente. A questão mais relevante para se compreender os termos do regime da OTAN que se forma, e suas conseqüentes implicações práticas nos primeiros anos da década de 1990, portanto, consiste em apreender o que se encontra subentendido no conceito de segurança de natureza heterogênea adotado pelo Conceito Estratégico em 1991 (NATO, 1991).

A agenda internacional conformada à época do colapso final do sistema comunista no continente europeu assume contornos mais cooperativos ao desbancar a preeminência dos assuntos de natureza militar característicos do período da Guerra Fria e atribuir destaque aos temas de política soft. A emergência de uma pauta mais abrangente e menos constrangedora (determinante) das relações estatais apresentou-se como efeito da reestruturação sistêmica desse período e refletia a esperança de uma "[...] nova e mais promissora era na Europa", relatadas no artigo de introdução ao texto do Conceito Estratégico. A crença em um vindouro mundo melhor e menos conflituoso no continente soa como o resgate do ideal kantiano, em que comércio e democracia surgem como os pilares de sociedades que vivem em harmonia, possibilitados pelo "triunfo" da ideologia ocidental após a queda do Muro de Berlim ${ }^{17}$.

A proposta americana de difundir sua visão de mundo, utilizando a OTAN como instrumento, coaduna-se com a expectativa européia de consolidar os valores democráticos e processos de cooperação na Europa. Interesse este que é demonstrado pelo "progresso substancial no controle de armas [que] já fortaleceu a estabilidade e a segurança na Europa pela diminuição dos níveis de armas e au-

\footnotetext{
17 A idéia de triunfo no texto remete à percepção pelos atores da inexistência de um modelo que oferecesse uma contraproposta alternativa e suficientemente atraente aos demais membros da comunidade internacional do Ocidente para o modelo de democracia liberal logo após o desmantelamento da URSS, que levou ao descrédito total a experiência do comunismo real.
} 
mentando a transparência militar e a confiança mútua" (idem, art. $3^{\circ}$ ), por meio, dentre outros instrumentos jurídicos, do adensamento do arranjo institucional do Conselho para Segurança e Cooperação na Europa, a CSCE, que "contribuiu significativamente para superar a divisão na Europa" (idem, art. $4^{\circ}$ ). A homogeneização de valores e processos econômicos entre os países europeus emerge como uma necessidade para a própria viabilização de uma União Européia que, já nos primeiros cincos anos da década de 1990, esforçou-se no sentido de aprofundar seus processos cooperativos e criar oportunidades para estender sua abrangência. Como era de se esperar, o regime de segurança da OTAN absorveu conceitualmente essa mudança da percepção dos atores envolvidos com relação ao papel da aliança.

Nesse sentido, declara o Presidente Bush, em 1992, acerca do posicionamento dos Estados Unidos frente aos aliados europeus, sua relação com a OTAN e as possibilidades que a organização oferece para estender os princípios liberais como base de reconstrução dos países recém afastados da influência soviética: "Presidentes de ambos os partidos lideraram uma Aliança Attântica unida pelos laços do princípio e amor à liberdade [...]. O povo americano demonstrou que iria suportar os custos de defesa, qualquer que fossem, e fazer qualquer sacrifício necessário para assegurar nossa liberdade e proteger nossos aliados e interesses. E nós fizemos uso dessa soberba tecnologia que nosso sistema de livre iniciativa produziu. E [os soviéticos] aprenderam que não poderiam dividir nossa aliança [...]. Recentemente, com os soviéticos em seu leito de morte, o potencial para crises e conflitos nunca foi maior. Conforme os povos da Europa Oriental caminhavam rumo à liberdade, nós os conduzimos por vias pacíficas. Eles se voltaram para nós. Eles se voltaram para a América, e nós não os viramos as costas. E quando nossos amigos alemães pegaram em seus martelos para derrubar aquele Muro, nós encorajamos uma Alemanha unificada, segura sob a proteção da OTAN [...]. Nós transformamos a Aliança Atlântica [...] em uma parceira de uma Europa mais unida, uma parceria primordialmente voltada para encarar novos desafios de segurança nessa época de incertezas. E o novo perfil de nossa aliança, a North Atlantic Cooperation Council, permite à OTAN englobar nossos antigos adversários do Pacto de Varsóvia" (BUSH, 1992).
A nova percepção das questões de segurança anunciada no Conceito Estratégico funda-se na garantia de estabilidade e na promoção de instituições livres e da economia de mercado nos países do continente. Os riscos a segurança dos países europeus, explica o artigo $9^{\circ}$, “[...] são menos prováveis de resultar da agressão calculada contra o território dos aliados do que serem decorrentes de conseqüências adversas de situações de instabilidade decorrentes de sérias dificuldades econômicas, políticas e sociais, incluindo rivalidades étnicas e disputas territoriais, enfrentadas por muitos países no Centro e Leste da Europa [...]" (NATO, 1991, art. $\left.9^{\circ}\right)^{18}$.

$\mathrm{O}$ aspecto mais interessante da definição de segurança adotada pelo documento é seu distanciamento das questões militares propriamente ditas e o vasto conjunto de alternativas políticas para a resolução de problemas referentes à segurança, isto é, a garantia de estabilidade e adaptação a um novo arcabouço institucional, de acordo com as diretrizes de 1991. A inclusão de formas alternativas de encarar a segurança para além das questões tradicionais proporcionadas pela redefinição da agenda internacional foi textualmente reconhecida no artigo 24: "[...] a oportunidade para alcançar os objetivos da organização através de meios políticos [...] [maior] do que nunca" (idem, art. 24). Assim apresentam-se as tarefas essenciais (mister) da Aliança Atlântica no tocante à segurança: "Providenciar os fundamentos indispensáveis para um ambiente de segurança estável na Europa, baseado no florescimento de instituições democráticas e o compromisso com a resolução pacífica de disputas, no qual nenhum país seja capaz de intimidar ou coagir qualquer nação

\footnotetext{
18 O novo foco para as questões de segurança também atendia aos interesses dos Estados europeus em resgatar a primazia sobre as decisões de segurança em seu continente, autoridade perdida com o fim da Segunda Guerra Mundial. Os europeus encaram os novos desafios de segurança como uma oportunidade de intensificar sua atuação nessa área, e não exclusivamente por meio da OTAN. A Western European Union (WEU), o equivalente militar da Comunidade Européia, ganha maior visibilidade e, em 1992, o Tratado de Maastrich oficializa o desejo da recém-criada União Européia de erigir uma política de segurança comum, batizada de Política Externa de Segurança Comum (PESC). Minimizar a dimensão militar significa diminuir o peso relativo da balança de poder nas decisões de segurança e, por conseqüência, no caso europeu, maior desvencilhamento da influência norte-americana.
} 
européia, ou de impor hegemonia por meio de ameaça ou uso da força; servir, como estipulado no artigo $4^{\circ}$ do Tratado do Atlântico Norte, como um fórum transatlântico para consulta entre os aliados em qualquer assunto que afete seus interesses vitais, inclusive possíveis desenvolvimentos que apresentem riscos para a segurança dos membros, e para coordenação apropriada de seus esforços em áreas de interesse comum; deter e defender contra qualquer ameaça de agressão contra o território de qualquer Estado membro da OTAN; preservar a balança estratégica na Europa" (idem, art. 20).

Embora as tarefas contempladas pelo documento incluam, nos últimos dois pontos, as funções para as quais a aliança foi originalmente pensada, a observação de que "a ameaça de ataques em grande escala, simultâneos, em todas as frentes européias foi efetivamente removida e, portanto, não constitui mais o foco da aliança estratégica [...]" (idem, art. $7^{\circ}$ ), revela a proeminência das novas questões de segurança a seus signatários.

Não obstante o documento ser explícito com relação aos objetivos futuros a serem perseguidos pela organização, ainda que de forma vaga, o Conceito Estratégico não discrimina com clareza quais eventos caracterizam-se como ameaças à segurança dos países europeus no período posterior à Guerra Fria, tampouco estipula que artifícios serão utilizados para restabelecer a ordem caso seja perturbada. Assim apresenta-se a questão no texto: "os riscos para a segurança dos aliados [encontram-se nas] conseqüências adversas de situações que podem originar-se de sérias dificuldades econômicas, políticas e sociais, incluindo rivalidades étnicas e disputas territoriais. [Tais] tensões, contanto que se mantenham limitadas, não ameaçam diretamente a segurança e a integridade territorial dos membros da aliança. Contudo, podem levar a crises inimigas a estabilidade européia e até evoluírem para um conflito armado, que poderia envolver potências externas ou atingir [spill-over] os países da OTAN, afetando diretamente dessa maneira a segurança da aliança" (idem, art. $9^{\circ}$ ).

Pode-se observar que, na realidade, a declaração encontrada no artigo $9^{\circ}$ indica somente a natureza dos possíveis elementos detonadores de situações de instabilidades e o contexto em que a segurança dos aliados possa, eventualmente, ser comprometida, sem especificar quais seriam esses elementos. "[O] conceito de ameaça à segurança é redigido de forma tão elástica que agora cobre tudo, desde reformas econômicas não concluídas até violações de direitos humanos e meio ambiente, sem definir qual o alcance desses conceitos" (FRANÇA, 2004, p. 119). Ou seja, qualquer sintoma de instabilidade de caráter econômico, político ou social, em qualquer país do continente, representa uma potencial ameaça aos membros da OTAN? Qual o critério para identificar uma situação de instabilidade de natureza econômica, política ou social prejudicial à segurança? Qual o momento certo de agir quando se suspeita da possibilidade de expansão de uma crise ou quando essa crise de fato começa a se expandir? $\mathrm{O}$ que se considera extensão da crise? Em nenhuma das 15 páginas de texto do documento encontramse respostas a essas ou outras perguntas interessadas em pontuar as características específicas da ameaça.

Conclui-se que a imprecisão da idéia de instabilidade incute à escolha dos atores um alto grau de flexibilidade frente às chances de agir, e atribui ao processo de definição da ameaça à segurança um caráter político. Isto é, a infinidade de fenômenos que podem ser considerados conseqüências nefastas advindas de instabilidades no meio político, econômico ou social, de acordo com a sugestão do documento analisado, torna os parâmetros de definição altamente subjetivos. Dessa maneira, a possibilidade de definir uma situação como ameaçadora à segurança de um país, seguindo interesses circunstanciais dos membros envolvidos, confere significativa margem de instrumentalização à Aliança.

Embora econômico quanto ao uso do termo prevenção, o sistema operacional previsto pelo conceito para cumprir as exigências do novo contexto de segurança europeu baseia-se quase exclusivamente nessa idéia. À exceção da defesa do território, o Comunicado Ministerial intitulado NATO's Core Security Functions in the New Europe reitera o propósito essencial da Aliança em "salvaguardar a liberdade e a segurança de seus membros por meios políticos e militares, de acordo com os princípios da Carta das Nações Unidas, [baseados] em valores comuns de democracia, direitos humanos e a regra da lei" (NATO, 1991b). Adiante, assegura a "manutenção de capacidade militar suficiente para prevenir a guerra e para 
garantir defesa efetiva, capacidade extensiva de administrar com sucesso crises que afetem a segurança de seus membros, o direcionamento do esforço político em favor do diálogo com outras nações" como os meios para alcançar sua política de segurança.

De fato, conforme atestam os eventos mais importantes da organização em 1991 o desenvolvimento de relações cooperativas com outros países evidencia-se como parte central do novo Conceito. E nesse sentido, a aliança avançou. Importante citar, em especial, as atividades proporcionadas pelos acordos do Combined Joint Task Force ("Força-Tarefa Combinada") e do Partnership for Peace ("Parceria para a Paz"), desenvolvidos já nos primeiros anos da década. Quanto à resolução de crises de instabilidade, pouco foi feito para uma maior especificação política dos conceitos normativos. A indefinição da aliança frente à escalada da violência no conflito da Bósnia, em parte decorre da ausência de regras de intervenção bem estabelecidas, embora a "doutrina aliada tivesse passado do equilíbrio global à prevenção de crises" (MIÑON, 1999, p. 57).

A falta de especificidade quanto à determinação de quadros políticos, econômicos ou sociais minimamente identificáveis, tais como fluxo maciço de refugiados ou a suspensão do processo eleitoral, por exemplo ${ }^{19}$, enquanto sinais de perigo eminente para a segurança confere (sugere) uma certa inconsistência nas propostas apresentadas no corpo do documento. Sintomaticamente, para a questão do uso da força, a incongruência reside na dificuldade de criar-se estratégias contra-ofensivas, de caráter preventivo, à adequada administração de crises. O sucesso das iniciativas em favor da paz realizadas pela Aliança Atlântica apóia-se com exclusividade na proposta da diplomacia preventiva, como explicita o artigo 31. Esse aspecto ressalta, uma vez mais, a importância da dimensão política nos assuntos de segu-

19 Evidentemente, não se pode prever toda a sorte de problemas que tenham origem na desestabilização econômica, política e social. No entanto, nem todo tipo de desequilíbrio desperta o interesse da OTAN em se envolver. Portanto, esse artigo aposta na possibilidade de a organização pontuar fenômenos considerados mais relevantes. Ainda que a imprevisibilidade dos fatos justifique certa margem de subjetividade, tais considerações poderiam transitar dentro de limites significativamente mais estreitos dos que os apresentados no planejamento estratégico. rança da OTAN ao adentrar em um cenário internacional cujos contornos de distribuição de poder e padrões de relacionamento entre estados ainda carecem de maior precisão. $O$ conceito reflete essa dificuldade ao propor métodos anacrônicos para atender os novos objetivos estabelecidos à aliança

Duas alternativas foram aventadas para explicar o caráter genérico que assume o problema da segurança no regime idealizado em 1991. A incerteza com relação à motivação de futuros conflitos e, mais relevante, a natureza diversificada dos fenômenos capazes de motivá-los, talvez tenham impossibilitado aos membros da OTAN a criação de um padrão de atuação adequado a essas novas ameaças.

Concretamente, o Conceito Estratégico não traça nenhuma linha relacionada à implementação de ações caso o modelo preventivo venha a falhar. Embora seu texto reitere, com constância, a primazia das questões políticas na garantia da segurança, o documento peca em concatenar os novos desafios estipulados, ou novas ameaças de natureza não militar, com elementos de natureza militar. A referência que se faz à atuação da aliança ainda encontra-se arraigada no uso tradicional da força, tal qual desenvolvido em 1949. Em outras palavras, o conceito de segurança coletiva absorveu novos temas, mas continuou exclusivamente pautado no princípio de defesa territorial. A intervenção armada para salvaguardar a estabilidade da região, a menos que encarada como uma violação direta à segurança de um de seus membros, não está prevista normativamente em 1991.

Ou seja, as questões de segurança no período posterior à Guerra Fria continuaram a ser tratadas pela lógica estratégico-militar, embora seja questionável se esse conteúdo mais poroso do conceito coaduna-se com este tipo de prática. Assim, segundo o artigo 35, "nunca nenhuma das armas da OTAN será usada exceto para autodefesa [...]" (NATO, 1991, art. 35). A amplitude interpretativa a que se presta a definição de ameaça, contudo, sugere que a concepção de autodefesa nesse contexto, de uso da força, portanto, recaia em uma decisão de caráter político, visto que a infinidade de eventos englobadas nessa percepção indistinta da ameaça permite a incorporação de interesses externos dos atores em ações designadas como meios de restaurar a paz.

Sem dúvida, um dos motivos condicionantes para a ausência de regras claras quanto ao 
restabelecimento da paz em casos de conflitos foi o zelo da organização pela Carta das Nações Unidas. Assim como em seu documento de origem, o Conceito Estratégico preocupa-se em esclarecer sua subordinação aos desígnios do órgão máximo no sistema internacional nas questões referentes à paz e à guerra, o Conselho de Segurança da ONU. A Carta que rege as ações do Conselho de Segurança não sofreu modificações textuais com a queda do Muro de Berlim. O que significa que o capítulo VII da Carta ainda legitima o uso da força exclusivamente em caso de agressão $^{20}$.

Por um lado, a necessidade de adaptação de suas funções e as limitações exógenas aos termos a serem adotados enquanto arranjo de segurança regional, em que se encontra classificada a OTAN, induz a essa sutil contradição. O Conceito Estratégico associa a segurança de seus membros a uma esfera que extrapola a legalmente permitida para sua atuação. A afirmação justifica-se ao identificarmos a necessidade da aliança de limitar sua ação armada à autodefesa para ser compatível com as prerrogativas do Conselho de Segurança da ONU. Portanto, para garantir o ambiente de estabilidade multifacetado, que julga saudável para segurança dos seus membros, enfatiza a prevenção.

Por outro, é plausível especular-se as eventuais conseqüências delicadas para a aliança de uma inconteste delimitação dos seus parâmetros decisórios acerca de iniciativas militares direcionadas a restaurar a estabilidade. A análise em retrospectiva aqui realizada permite-nos lançar tal argumento com maior grau de certeza, em especial quando se coloca em foco a lentidão com que as potências mundiais responderam aos conflitos étnicos na Bósnia e o conjunto de variáveis de interesse clássicos associados a Realpolitik que interferiram no processo. Vale lembrar que a concepção de segurança adotada pela OTAN para guiar seus passos a partir de 1991 assume uma postura fundamentalmente valorativa. Ao contrário do período da Guerra Fria, em que seu funcionamento encontrava-se estritamente associado a querelas de teor geopolítico, o Conceito Estratégico aponta qualquer desvio na instituição de

20 Houve, contudo, de acordo com Patriota (1998), uma nova forma de interpretar os artigos da Carta referente à intervenção armada após da Guerra do Golfo. processos democráticos e difusão dos valores liberais como uma anomalia capaz de desestruturar a ordem. Lida no espelho, a segurança dos paísesmembros está diretamente associada, portanto, ao fortalecimento da democracia liberal no continente europeu.

No entanto, a própria preocupação do Conceito em associar de forma mecânica a ameaça de instabilidade à autodefesa demonstra satisfatoriamente os limites da premência dos aspectos valorativos, à época da formulação do documento. De certa maneira, significa a ciência por parte dos países-membros da fragilidade da diplomacia preventiva enquanto instrumento capaz de manter a ordem. No mínimo, o reconhecimento de que a organização não poderia, ou seus atores não estariam dispostos a comprometerem-se por incertas demandas à estabilidade advindas da responsabilidade de disseminar os valores liberais indiscriminadamente no continente europeu.

A leitura que aqui se fez do documento elaborado pela OTAN em 1991, tentou identificar as principais mudanças que se processaram na percepção das questões de segurança, referentes ao uso da força, com o fim da Guerra Fria, comparandoas com o Tratado de Washington de 1949, e buscou, também, apreender de que forma a Aliança Atlântica transformou-as em seus objetivos institucionais.

Resumidamente, as conclusões da análise demonstram que o conceito de segurança deixou de ser uma questão meramente geopolítica e adquiriu uma natureza mais abrangente, cujos parâmetros seriam os valores da democracia liberal e da sociedade de mercado, que atribuem à estabilidade política, econômica e social do continente a condição de garantia da segurança. Embora o Conceito Estratégico sugira o investimento em ações preventivas, peca em estabelecer meios de reverter situações de crise que abalam a paz na região caso esse modelo de atuação não seja eficaz. De tal sorte que a garantia da estabilidade continuou pautada nos requisitos estratégico-militares de defesa coletiva tradicional ao associar, necessariamente, a prática militar à autodefesa.

\section{O CONCEITO ESTRATÉGICO DE 1999: VARIAÇÕES NO REGIME DE SEGURANÇA DA OTAN NO FINAL DA DÉCADA}

A dificuldade de operacionalizar o conceito de segurança previsto pela Aliança Atlântica em 1991 
pode-se sentir logo na primeira prova enfrentada pela organização, a Guerra da Bósnia. Um grave e prolongado conflito, cuja dinâmica não apresentava nenhuma ameaça direta à segurança dos países membros, sem dúvida consistia em uma fonte de instabilidade que colocava em risco as instituições e os valores democrático-liberais, confirmado pela massiva violação dos direitos humanos desde a etapa inicial do conflito ${ }^{21}$.

A elaboração de um novo conjunto de diretrizes para a OTAN inicia-se em 1997 e culmina com a ratificação de mais um Conceito Estratégico em 1999. A Reunião de Cúpula de Madri, realizada em junho do ano citado, tinha em vista a continuidade do "processo de revisão da estratégia da organização e do perfil que teria no século XXI", e confirmou sua validade enquanto "uma instituição relevante para a segurança européia [...]" (CASTILHOS FRANÇA, 2004, p. 109). Revisitar o conteúdo do documento ratificado em 1991, e substituí-lo em 1999, foram decorrências da percepção declarada, já no segundo artigo das novas estratégias, de que esse intervalo de anos vivenciou "profundos desenvolvimentos políticos e na área de segurança" (ibidem).

Embora a organização alegasse necessidade de reavaliar seu projeto, o novo texto adotado em seu $50^{\circ}$ aniversário na sua maior parte reitera os compromissos firmados na primeira versão. A distinção significativa refere-se a uma maior especificação de seu conteúdo. $\mathrm{O}$ documento moldado no final da década de 1990 estabelece com mais clareza os elementos condicionantes da atuação da aliança. Outro ponto que merece destaque é o refinamento da relação imediata entre segurança e estabilidade previamente realizada. Convém iniciar a discussão pelo segundo ponto.

$\mathrm{O}$ ambiente estratégico no qual a OTAN desenvolvia suas atividades pouco se diferenciava daquele anunciado em 1991: a improbabilidade de uma agressão direta a alguns de seus membros e a susceptibilidade dos países aliados terem sua segurança abalada por uma "ampla gama de riscos [...] não-militares" (NATO, 1999, art. 20). O reconhecimento da natureza multidimensional da ameaça garantiu uma abordagem extensiva da noção de segurança, que inclui "fatores políticos,

21 A literatura constata a implementação da política de limpeza étnica por todas as partes desde 1992, data oficial do início do conflito. econômicos, sociais e ambientais, adicionados à dimensão indispensável da defesa" (idem, art. 25). De fato, o documento atribui o sucesso da aliança em preservar a estabilidade do continente Europeu na década de 1990, ao mencionar sua presença decisiva nos conflitos balcânicos, exatamente a essa definição heterogênea de segurança (idem, art. $3^{\circ}$ ).

No entanto, ao contrário das formulações de 1991, o problema da estabilidade, alçada ao plano de estratégia central da organização, ganha outro contorno e assume parte de uma relação causal nos preceitos normativos que guiarão os seguintes passos da aliança. De acordo com a argumentação da segunda parte do presente artigo, o Conceito Estratégico precedente, desenvolvido pelos representantes dos países membros, designou duas funções para a organização. Em primeiro lugar, a OTAN responsabilizar-se-ia por assegurar a paz na região euro-atlântica ao conter eventuais instabilidades decorrentes da alteração do equilíbrio de poder propiciado pela queda e fragmentação do império soviético. Isto é, a aliança contribuiria para dirimir distúrbios econômicos, políticos e sociais resultantes de transformações estruturais ou reivindicações de cunho étnico ou nacionalista nos estados da Europa Central e do Leste (NATO, 1991 , art. $7^{\circ}$ ). O engajamento não militar da organização Atlântica em tais eventos, por meio da diplomacia preventiva, estaria condicionado à percepção de iminente ameaça que um abalo na periferia da área abarcada pela aliança causaria à segurança de seus membros.

A segunda questão refere-se à manutenção do mecanismo de defesa coletiva, previsto nas cláusulas originais de criação da OTAN, o Tratado de Washington. Ambas as funções continuam previstas pelo regime que se instaura, às portas do novo milênio. No entanto, inverte-se a relevância de uma e da outra no plano normativo.

A proposta inicial do Conceito Estratégico de 1991 analisa o porvir no cenário internacional de maneira positiva. Confiante na convergência de aspirações e interesses entre os partícipes da aliança e ex-membros da URSS quanto às bases de sustentação de uma Europa unificada pelos valores, a organização elegeu medidas cooperativas nos campos político, econômico e militar como o cavalo de batalhas no seu esforço de minimizar o potencial de instabilidade na região. Prevenir conturbações na arena européia consistia no cerne das 
preocupações da OTAN em 1991, devido à relação simbiótica que se formulou entre estabilidade e segurança.

Embora o documento atribua a encaminhamentos indesejados de distúrbios na região euro-atlântica a principal fonte de ameaça à segurança dos países membros, nem toda convulsão de ordem política, econômica ou social caracteriza-se por risco à liberdade e à soberania dos demais estados. Esse tipo de circunstância desestabilizadora, mas que não possui implicações diretas nos processos internos das potências comprometidas com pacto de segurança coletiva regional, conduz a uma paralisia quando se trata do critério de ação estipulado pelos trâmites institucionais. Ou seja, o caráter não previsto normativamente de contenção de conflitos que não por meios políticos reside nas restrições ao uso da força, dedicado, de acordo com o artigo 35, exclusivamente ao caso de autodefesa. Observe-se o caso emblemático do conflito étnico oficialmente deflagrado na Bósnia em 1992.

O envolvimento mais incisivo nos primeiros anos da Guerra da Bósnia por parte da aliança sofreu uma série de constrangimentos circunstanciais, como a incapacidade de coordenação entre os membros europeus acerca da postura a ser adotada pela organização e a falta de liderança dos Estados Unidos em decorrência de dificuldades no âmbito doméstico enfrentadas pelo Presidente norte-americano Bill Clinton ${ }^{22}$. De qualquer modo, considerada como uma crise humanitária, cuja dinâmica não apresentava perigo à segurança política e territorial dos países da aliança, a única solução prevista para o engajamento da OTAN, de acordo com suas diretrizes estratégicas, era a negociação.

Já as vésperas de adotar o Conceito Estratégico de 1999, a disputa armada no Cosovo possuía, por outro lado, uma importância distinta no contexto europeu. A possibilidade latente de o confli-

\footnotetext{
22 A forte recessão econômica que assolava os Estados Unidos nesse período direcionou as atenções da opinião pública e da campanha presidencial de fins de 1992 para os assuntos domésticos, marginalizando as questões externas. Embora o envolvimento norte-americano com a situação na Bósnia date de 1993, ele foi esporádico em suas demonstrações públicas e majoritariamente extra-oficiais. As iniciativas mais incisivas do governo Clinton para encontrar meios de terminar o conflito remetem a meados de 1994. Para mais detalhes, ver Viggiano (2005).
}

to alastrar-se para a Albânia e a Macedônia concedeu ao embate entre sérvios e albaneses uma dimensão geoestratégica ausente na guerra balcânica que a antecedeu. Embora uma modificação no status quo territorial da Europa afetasse de forma mais agressiva a segurança da região, por abrir um precedente, a ênfase para a intervenção deu-se na violação maciça dos direitos humanos. Ao não se concentrar nas eventuais conseqüências nefastas para a segurança dos países da Europa Ocidental, o Conceito mostrou, mais uma vez, que não contemplava em suas premissas o envolvimento militar da organização no embate.

A incompatibilidade entre o conceito de segurança, baseado na estabilidade, e a viabilidade normativa de usar a força em seu nome foi sanada, de alguma maneira, no Conceito Estratégico de 1999. O documento desvincula, parcialmente, a segurança dos membros da organização da questão da estabilidade ao inverter e limitar seu propósito.

Ao reconhecer a natureza distinta das ameaças que podem infligir insegurança aos países membros da OTAN no contexto posterior à Guerra Fria, o sétimo artigo do texto, ratificado em 1991, determina o direcionamento a ser adotado pelas políticas da aliança da seguinte forma: "Os desafios e riscos à segurança que a OTAN enfrenta são diferentes na sua natureza daqueles do passado. A ameaça de ataque em grande escala, simultâneos, em todas as frentes européias foi efetivamente removida e, portanto, não constitui mais o foco da aliança estratégica [...]" (ibidem). Essa afirmação permite concluir que a questão da defesa territorial foi relegada a segundo plano, para ser substituída, como se argumenta acerca do documento elaborado em 1991, por ações preventivas capazes de dirimir a potencialidade conflitiva contida nas transformações, então em andamento, do ambiente político da região.

A diferença fundamental percebida no documento de 1999 refere-se a uma alteração da prioridade estratégica da aliança. Como indica o artigo $6^{\circ}$, "o propósito essencial e duradouro da OTAN, estabelecido no Tratado de Washington, é resguardar a liberdade e a segurança de seus membros por meios políticos e militares" (NATO, 1999, art. $\left.6^{\circ}\right)$. Na realidade, o que se observa é um retorno à proposta inicial de 1949 de garantir a integridade dos membros da organização, ainda que os termos cunhados no texto do final da década 
de 1990 transcendam de forma mais explícita a função de defesa territorial. Ao incluir a idéia de garantia da liberdade, por meios políticos tanto quanto militares, a aliança mantém a linha de raciocínio desenvolvida em 1991 e reafirma seu compromisso com a segurança coletiva.

No entanto, a relação entre segurança e estabilidade não foi completamente rompida, o que explica a hipótese, acima mencionada, de sua desvinculação parcial. A percepção da OTAN, no que diz respeito aos riscos que eventuais situações de instabilidade na região podem ocasionar à segurança de seus membros, continua presente no corpo do documento de 1999. Contudo, ao invés de incorporar a tentativa de evitar a deflagração de crises como sua função primordial, a organização limita-se a declarar que "não somente assegura a defesa de seus membros, mas também contribui para a paz e a estabilidade na região" (ibidem). Nesse sentido, a manutenção de relações estáveis, de alguma forma, aparece como conseqüência da própria busca dos países aliados por um ambiente seguro. Vale ressaltar que a OTAN não deixa de desenvolver políticas cooperativas, com o intuito de "preservar a paz, prevenir a guerra e fortalecer a segurança e a estabilidade" (idem, art. 31); e de encará-las como fundamentais para a segurança da organização, uma vez que "riscos complexos [...], tais como opressão, conflitos étnicos, dificuldades econômicas, o colapso de ordens políticas e a proliferação de armas de destruição em massa" (idem, art. $3^{\circ}$ ) podem minar a estabilidade da região e, por extensão, intervir de forma negativa nos interesses dos estados participantes. Não obstante, a garantia da estabilidade perdeu o posto de função básica e passou a ser tarefa complementar da organização, unicamente enquanto forma de servir à segurança de seus membros.

O segundo ponto significativo que merece ser analisado refere-se aos determinantes para o uso da força. De acordo novamente com o artigo 35, anunciado em 1991, a organização disporia as armas somente em favor da autodefesa. A indefinição frente ao que seria uma ameaça que justificasse a reclamação da autodefesa suscita duas considerações contraditórias. Por um lado, ao associar a garantia da segurança à estabilidade, a instituição encontrava-se presa à utilização de medidas preventivas, pois a impossibilidade de agir em nome da autodefesa em situações de pouca relevância imediata para os países membros tornava-se um constrangimento ao uso da força. Por outro, a maleabilidade do conceito de ameaça, que não aparece de forma lapidada nas linhas do Conceito Estratégico de 1991, permitia certa flexibilidade política com relação à determinação do que se entende por autodefesa.

No que diz respeito ao uso da força, no entanto, a publicação de 1999 não faz menção, em nenhum dos seus artigos, a delimitações específicas quanto à intervenção armada, pelo contrário. A OTAN, a partir dessa data, disponibiliza sua capacidade militar para conduzir operações não previstas pelo artigo $5^{\circ}$ do Tratado de Washington ${ }^{23}$. Dessa maneira, a organização liberta-se das amarras que enredam sua atuação bélica.

As duas questões trabalhadas, a inversão nas funções da organização e a perda de especificação quanto ao uso da força, correm em sentido inverso quando se considera suas implicações para o regime. Ou seja, enquanto o enfoque pautado na segurança coletiva dos membros da aliança restringe a sua atuação, a possibilidade de fazer uso de seu potencial militar para sanar crises alheias às previstas pelo artigo $5^{\circ}$ do Tratado do Atlântico Norte permite a organização estender suas atividades para além do campo de atuação previamente estipulado. Nesse espaço de intersecção entre essas duas perspectivas paradoxais é que a questão dos direitos humanos, no bojo da defesa dos valores liberais, passa a integrar de forma mais explícita o regime da organização.

Assim como em 1991, a expressão "intervenção humanitária" não permeia o vocabulário do documento de 1999. No entanto, os direitos humanos aparecem textualmente como valores a serem perseguidos pela comunidade dos países aliados do mesmo jeito que situações de emergência humanitária surgem como singular exemplo que justificaria o envolvimento da organização em crisis management. $\mathrm{O}$ artigo 31 faz a seguinte observação a respeito do tema da resolução de crises: "Ao perseguir sua política de preservar a paz, prevenir a guerra e fomentar a segurança e a estabilidade, [...] a OTAN procurará, em cooperação com outras organizações, prevenir confli-

\footnotetext{
23 O artigo $5^{\circ}$ do Tratado do Atlântico Norte, ou Tratado de Washington, é exatamente aquele que atribui à aliança seu caráter de defesa coletiva.
} 
tos, ou, caso se deflagre uma crise, contribuir efetivamente para sua resolução, [...] incluindo a possibilidade de conduzir operações responsivas não previstas pelo artigo $5^{\circ}$. A prontidão da aliança em comandar operações dessa natureza se alicerça no objetivo mais amplo de reforçar e expandir a estabilidade e freqüentemente envolve parceiros da OTAN" (NATO, 1999, art. 31).

Apesar da disposição demonstrada nessas linhas em contribuir para o apaziguamento de conflitos, o décimo artigo apresenta um importante porém. Afirma o artigo $10^{\circ}$ que em situações de crisis management a OTAN estará alerta, mas sua atuação será decidida "caso por caso, e via consenso, em conformidade com o artigo $7^{\circ}$ do Tratado de Washington, para contribuir de forma efetiva para a prevenção de conflitos e para se engajar ativamente nas resoluções de conflito, inclusive em operações responsivas a crises" (idem, art. $\left.10^{\circ}\right)$. A proposta de decisões ad hoc sobre o envolvimento da organização no conflito remete novamente à dimensão política primordial que assume a OTAN nos anos 1990. Nesse sentido, o Conceito de 1999 oferece ainda maior flexibilidade política aos membros da aliança que o documento de 1991. No final da década, seu preceito normativo contempla tanto a opção política de agir quanto a de não agir, enquanto em 1991, devido aos constrangimentos estipulados pelo conceito de autodefesa, os limites legais no plano estratégico da organização justificavam somente a ação. Portanto, desvincula a obrigatoriedade da intervenção, mas a viabiliza, sob o manto de garantir a segurança do ambiente. A possibilidade de atuar da maneira que for mais conveniente aos membros da organização, sem desrespeitar os pressupostos do Conceito, confere maior mobilidade e legalidade à OTAN, o que explica, de certa forma, a opção por restringir sua função principal.

Para os propósitos desse trabalho, o conceito de intervenção humanitária é definido pelas palavras de Holzgrefe: "a ameaça ou uso da força através das fronteiras de um Estado por outro Estado (ou grupo de estados) com o objetivo de prevenir ou findar grave e disseminada violação dos direitos humanos fundamentais de indivíduos outros que não seus cidadãos, sem a permissão do Estado em cujo território a força é aplicada" (HOLZGREFE, 2003, p. 18). Embora a operacionalização desse conceito em tais moldes seja relativamente contemporânea, a idéia da in- tervenção humanitária não consiste em um fenômeno recente. Ao longo da história, pode-se verificar que a violação de fronteiras com o objetivo de resgatar povos vítimas de desastres humanitários, dá-se quando os estados interventores com eles identificavam-se. A diferença fundamental entre a prática intervencionista antes e depois de 1945 reside na alteração dos critérios utilizados para qualificar a natureza da ação, decorrentes do caráter interativo e interdependente das normas que influenciam o comportamento internacional (FINNEMORE, 2003), isto é, uma alteração na percepção e definição de direitos humanos.

A forma exclusivista de identidade calcada em aspectos unidimensionais, alicerce do intervencionismo humanitário no século XIX e início do século $\mathrm{XX}^{24}$, foi substituída por uma percepção universal de "humanitarismo". A Declaração Universal dos Direitos Humanos, adotada e proclamada pela assembléia Geral da ONU em 10 de dezembro de 1948, institucionaliza o princípio da igualdade jurídica dos homens ${ }^{25}$, sem distinção de nenhuma natureza. Portanto, a partir dessa data, legaliza-se a percepção abrangente do "humanitário" como reflexo do processo de mutação na crença da comunidade internacional.

As duas últimas guerras nos Bálcãs vêm atestar a ineficiência da Carta em garantir tais direitos, e confirma a completa inexistência de mecanismos estabelecidos normativamente para controlar seu cumprimento ou punir as violações (ALVES, 1997). A dificuldade em se estabelecer mecanismos de verificação encontra barreiras na própria organização do sistema, respaldada no direito internacional. Uma medida dessa natureza infringiria o direito de soberania e autodeterminação dos estados, e, portanto, criaria um precedente para violação de qualquer outra ordem a esses direitos. A intervenção armada para defender os direitos humanos, estudada caso por caso, tal como propõe o regime da OTAN, foi a maneira encontrada para a aliança responder às pressões internacionais, fortemente realizadas pela mídia e pela opinião pública, em alguns momen-

\footnotetext{
24 Por exemplo, a intervenção com bases em crenças religiosas. Para descrições de intervenções ocorridas no século XIX e início do XX, ver Finnemore (2003, p. 58-66).

25 Pois, na verdade, a proposta em si da igualdade dos homens remete à revolução Francesa.
} 
tos particulares, como após o massacre de Zepa e Srebrenica ${ }^{26}$ na guerra da Bósnia, e o massacre de Racak, no conflito do Cosovo.

Sem dúvida, a adoção de intervenções como política para solucionar conflitos, por meio de crisis management, para não se afastar dos termos do Conceito Estratégico, extrapola os limites legais do direito internacional ${ }^{27}$. No entanto, a validade desse tipo de ação goza de algum reconhecimento ${ }^{28}$. De acordo com as modalidades de intervenção humanitária relacionadas por Stromseth, a OTAN encaixar-se-ia no que denomina de excusable breach. Essa perspectiva política, embora considere a intervenção humanitária como tecnicamente ilegal sem um mandato expresso da $\mathrm{ONU}^{29}$, acredita que o uso da força "pode ser moral e politicamente justificáveis em certas circunstâncias especiais [e que] [...] a extraordinária circunstância de cada situação seja confrontada e analisada caso por caso" (STOMSETH, 2003, p. 242). A opção por essa modalidade, como faz o regime da OTAN, traz benefícios por reconhecer "a natureza verdadeiramente excepcional da legítima intervenção humanitária não-autorizada" (STROMESETH, 2003, p. 243). Na realidade, a

26 Em setembro de 1995, após o ocorrido, “[o] apoio potencial de tropas norte-americanas em esforços aliados angaria uma substancial maioria de norte-americanos que acreditavam que tanto as preocupações realistas de impedir que a guerra se alastrasse $(63 \%)$ quanto o desejo humanitário de cessar as atrocidades (64\%), justificavam o envio de forças dos EUA (CBS, 12/9/1995)" (SOBEL, 1998, p. 255).

27 Ultrapassa o escopo desse trabalho analisar a legalidade das ações intervencionistas. Para um estudo mais detalhado sobre o tema, ver França (2004, cap. $5^{\circ}$ ).

28 Embora a OTAN tenha desrespeitado a superioridade legal do Conselho de Segurança, nem o Conselho tampouco o Secretário Geral da ONU condenaram a ação da aliança no Cosovo. "[...] O Conselho de Segurança rejeitou a resolução que taxaria a ação da OTAN uma violação à Carta. O Secretário Geral Annan [...] enfatizou a deficiência da Carta da ONU em providenciar refúgio para aqueles vítimas de atrocidades" (STROMSETH, 2003, p. 242).

29 Novamente, sem desconsiderar a importância e interdependência entre as questões aqui trabalhadas e a legalidade da intervenção, a pesquisa preocupa-se em trabalhar a legalidade no âmbito do regime da OTAN, de acordo com o recorte realizado. Para fins de melhor compreensão das citações transcritas, a idéia de ilegalidade para a autora alicerça-se na autorização da ONU para as intervenções humanitárias. incorporação das questões de direitos humanos ao regime de 1999, embora estas não estejam exclusivamente associadas à intervenção ${ }^{30}$, soa como reflexo da aceitação legítima por parte dos países membros das operações realizadas nos Bálcãs no intervalo de anos entre o primeiro e o segundo Conceito Estratégico.

A questão da legitimidade é tratada de duas maneiras nesse artigo: a legitimação da forma e do conteúdo da ação intervencionista. A mudança na percepção provocada pela institucionalização dos direitos humanos gera uma sensibilidade negativa do ato unilateral, tal como acontecia com as intervenções do passado, por parte da opinião pública, que passa a encará-lo como uma atitude particularista dos estados. Ou seja, para serem consideradas politicamente legítimas ${ }^{31}$, as intervenções humanitárias a partir desse momento, devem assumir um caráter multilateral (FINNEMORE, 2003). A postura dos membros da OTAN condiz com o desencadeamento lógico da noção de direitos humanos universais. A premissa universalista exige que o reconhecimento da violação de tais direitos seja encarado como uma ofensa que agride o princípio valorativo defendido por todos, ou, pelo menos, por vários daqueles que compartilham dessa mesma visão de mundo.

A proposta de Stromseth sugere a emergência "de uma norma costumeira do direito internacional na qual a intervenção humanitária poderia ser considerada legal em casos raros, sob certas circunstâncias" (STROMSETH, 2003, p. 246). Em outras palavras, essa forma não-institucionalizada de ingerência procuraria identificar um determinado padrão nos conflitos em que a comunidade internacional tenha se envolvido para justificar persuasivamente a ação. No entanto, a primazia da dimensão política nas decisões sobre crisis managemet no Conceito Estratégico de 1999, de-

\footnotetext{
30 A aliança cuida de tratar a intervenção de maneira eufemística. As expressões "crisis management" e "operações responsivas a crises" empregados quando relacionados ao uso da força e não à negociação ganham o mesmo significado de "intervenção".

31 Foge ao escopo do trabalho discutir a legitimidade jurídica da intervenção humanitária, embora seja uma questão relacionada ao problema aqui analisado. Sobre esse tema, consultar Byers e Chesterman (2003) e França (2004, em especial cap. $5^{\circ}$ e $6^{\circ}$ ).
} 
monstra a ausência de interesse da aliança em definir critérios claros para sua atuação.

Ainda que, caso a caso, o grande feito do Conceito Estratégico instituído em 1999 foi o de permitir à organização a chance de agir de forma mais eficaz em nome dos valores promulgados pela aliança. Em outras palavras, o documento vislumbra a possibilidade de usar a força, a ultima ratio, para fazer valer a manutenção das idéias democrático-liberais na Europa.

\section{CONSIDERAÇÕES FINAIS}

Esse trabalho procurou discorrer sobre o regime da OTAN ao longo da década de 1990. Inicialmente modificado em 1991, o Conceito Estratégico da Aliança Atlântica procurou adaptar as diretrizes da organização aos novos desafios que o contexto posterior à Guerra Fria oferecia à segurança dos países aliados. Pautada nas questões políticas, econômicas e sociais, o novo conceito de segurança adotado apontou como o cerne das preocupações de segurança as eventuais situações de instabilidades na região euro-atlântica.

No entanto, se a OTAN logrou apreender as peculiaridades que a iminente configuração do cenário internacional apresentava, a organização não foi capaz de conciliar essa percepção aos mecanismos de atuação a serem utilizados para combater as ameaças esperadas.

A proposta normativa disposta nos artigos do documento de 1991 privilegiava as ações preventivas como forma de dirimir as instabilidades decorrentes do processo de transformação política e econômica que os países da Europa Central e do Leste enfrentavam. Na realidade, não somente privilegiava como não previa nenhum outro tipo de ação que pudesse ser comportada pelos preceitos estabelecidos. Essa situação de limitação operacional decorre do fato de que o uso da força continuava atrelado à definição original, concebi- da em 1949. Ou seja, as armas da OTAN só seriam disponibilizadas para garantir a autodefesa de seus membros.

Reservar o uso da força para a autodefesa significa não contemplar a possibilidade de intervir militarmente em ocasiões em que nem as ações preventivas nem as negociações sejam bem sucedidas em findar uma crise. Além disso, há falta de especificação com relação ao que se consideram momentos de instabilidade capazes de interferir no interesse dos países aliados. Isto é, a ausência de um enquadramento padronizado de situações que poderiam ser consideradas como ameaçadoras à segurança dos membros da organização - e, portanto, justificar a utilização da força em nome da autodefesa - atribui um forte teor político aos processos decisórios.

Essas debilidades foram solucionadas pelo documento de 1999, também intitulado Conceito Estratégico que substituiu as primeiras diretrizes estratégicas da aliança, implementadas ainda no mesmo ano do desmembramento da União Soviética. Em especial, a OTAN dissociou o uso da força exclusivamente das questões de autodefesa. Essa alteração criou um espaço, no âmbito normativo, para que a aliança de fato se adaptasse ao novo conceito de segurança já fixado em 1991, e vislumbrasse a utilização de instrumentos militares para crisis manegement.

A análise aqui realizada permite concluir que houve, de fato, um aprimoramento do regime da OTAN na década de 1990. As mudanças fundamentais residem no retorno do foco às funções originalmente desempenhadas, que ganham um apimentado tempero político, e na contemplação normativa do uso da força tanto para a atuação quanto para a omissão do seu envolvimento em casos que não se caracterizam como autodefesa.

Juliana Lyra Viggiano Barroso (juviggiano@usp.br) é mestre em Ciência Política pela Universidade de São Paulo (USP), doutoranda do Departamento de Ciência Política da mesma instituição e professora do curso de Relações Internacionais da Universidade Anhembi Morumbi. 


\section{REFERÊNCIAS BIBLIOGRÁFICAS}

AGUILAR, S. 2003. A guerra da Iugoslávia : uma década de crise nos Bálcãs. São Paulo : Usina do Livro.

ALBRIGHT, M. K. 1998. The Testing of American Foreign Policy. Foreign Affairs, Palm Coast, v. 77, n. 6, p. 50-64, Nov.-Dec.

ALBUQUERQUE, J. A. G. 1993. Bill Clinton : um presidente para que século?. Politica Externa, São Paulo, v. 1, n. 4, p. 79-94, mar.

ALENCAR, K. 1999. Kosovo : a guerra dos covardes. São Paulo : DBA.

ALVES, J. A. L. 1997. A arquitetura internacional dos direitos humanos. São Paulo : FTD.

ANING, E. K. 1997. A dinâmica do regime de segurança da Ecowas : limitações e perspectivas. Contexto Internacional, Rio de Janeiro, v. 19, n. 1, p. 71-96, jan.-jun.

ART, R. J. 1998. Creating a Disaster : NATO's Open Door Policy. Political Science Quarterly, New York, v. 113, n. 3 , p. 383-403, Fall.

BANKS, W. C. \& STRAUSSMAN, J. D. 1999. A New Imperial Presidency? Insights from U.S. Involvement in Bosnia. Political Science Quarterly, New York, v. 114, n. 2, p. 195-217, Summer.

BLECHMAN, B. \& WITTES, T. C. 1999. Defining Moment : the Threat and Use of Force in American Foreign Policy. Political Science Quarterly, New York, v. 114, n. 1, p. 1-30, Spring.

BORAWSKI, J. 1995. Partnership for Peace. International Affairs, London, v. 71, n. 2, p. 233-246, Apr.

BOYD, C. G. 1998. Making Bosnia Work. Foreign Affairs, Palm Coast, v. 77, n. 1, p. 42-55, Jan.Feb.

BROWN, M. E. 1999. A minimização da OTAN. Gazeta Mercantil, São Paulo, p. 17-22, 11.jun. Caderno Foreign Affairs (edição brasileira).

BRZEZINSKI, Z. 1992. Acordos globais seletivos. Política Externa, São Paulo, v. 1, n. 1, p. 42-57, jun.

BUSH, G. 1992. Remarks at Texas A\&MUniversity in College Station, Texas. Public Papers of the
President. Washington, D. C. : U.S. Government Printing Office. Disponível em : http:// frwebgate 5.access.gpo.gov/cgi-bin/ waisgate.cgi? WAISdocID $=04542667611+1$ $+0+0 \&$ WAISaction $=$ retrieve. Acesso em : 17.dez.2004.

BYERS, M. \& CHESTERMAN, S. 2003. Changing the Rules about Rules? Unilateral Humanitarian Intervention and the Future of International Law. In : HOLZGREFE, J. L. \& KEOHANE, R. O. (eds.). Humanitarian Intervention : Ethical, Legal, and Political Dilemmas. Cambridge : Cambridge University.

CAPLAN, R. 1998. International Diplomacy and the Crisis in Kosovo. International Affairs, London, v. 74, n. 4, p. 745-761.

CASTRO, J. 1999-2000. Kosovo e o novo sistema de segurança internacional. Política Externa, São Paulo, v. 8, n. 3 , p. 98-113, dez.fev.

CHOMSKY, N. 2003. Uma nova geração define o limite : os verdadeiros critérios das potências ocidentais para suas intervenções militares. Rio de Janeiro : Record.

CROFT, S.; HOWORTH, J.; TERRIFF, T. \& WEBER, M. 2000. NATO's Triple Challenge. International Affairs, London, v. 76, n. 3, p. 495-518.

CVIIC, C. 1995. Review article : Perceptions of the Former Yugoslavia : An Interpretative Reflection. International Affairs, London, v. 71, n. 4, p. 819-826.

DRAPER, T. 1992. A Guerra do Golfo reconsiderada. Política Externa, São Paulo, v. 1, n. 1, p. 75-94, jun.

DUFFIELD, J. S. 1994-1995. NATO’s Functions after the Cold War. Political Science Quarterly, New York, v. 19, n. 5 , p. 763-787, Winter.

EYAL, J. 1997. NATO's Enlargement : Anatomy of a Decision. International Affairs, London, v. 73 , n. 4 , p. $695-719$, Oct.

FERON, B. 1999. Iugoslávia : a guerra do final do milênio. Das origens do conflito aos bombardeios da OTAN. Porto Alegre : L\&PM.

FINNEMORE, M. 2003. The Purpose of 
Intervention. Changing Beliefs about the Use of Force. Ithaca : Cornell University.

FONSECA JÚNIOR, G. 1995. O sistema internacional durante a Guerra Fria. Revista da USP, São Paulo, n. 26, p. 130-137, jun.-ago.

FRANÇA, P. R. C. C. 2004. A Guerra do Kosovo, a OTAN e o conceito de "intervenção humanitária”. Porto Alegre : UFRS.

GOLDSTEIN, J. \& KEOHANE, R. O. 1993. Ideas and Foreign Policy : an Analytical Framework. In : . (eds.). Ideas and Foreign Policy : Beliefs, Institutions, and Political Change. New York : Cornell University.

HARTLEY, K. \& SANDLER, T. 1999. NATO Burden-Sharing : Past and Future. Journal of Peace and Reasearch, v. 36, n. 6, p. 665-680, Nov.

HOLZGREFE, J. L. 2003. The Humanitarian Intervention Debate. In : HOLZGREFE, J. L. \& KOEHANE, R. O. (eds). Humanitarian Intervention : Ethical, Legal, and Political Dilemmas. Cambridge : Cambridge University.

HUNTER, R. E. 1999. A maximização da OTAN. Gazeta Mercantil, São Paulo, p. 23-29, 11.jun. Caderno Foreign Affairs (edição brasileira).

IGNATIEFF, M. 1993. A tragédia dos Bálcãs. Política Externa, São Paulo, v. 2, n. 2, p. 311, set.

LEPGOLD, J. 1998. NATO's post-Cold War Collective Action Problem. International Security, v. 23, n. 1, p. 78-106.

LIGHT, M.; WHITE, S. \& LÖWENHARDT, J. 2000. A Wider Europe : the View from Moscow and Kyiv. International Affairs, London, v. 76, n. 1 , p. $77-88$.

KENNAN, G. F. 1993. A crise dos Bálcãs : 1913 e 1993. Política Externa, São Paulo, v. 2, n. 3 , p. 71-84, dez.

KEOHANE, R. O. 1984. After Hegemony : Cooperation and Discord in the World Political Economy. New Jersey : Princeton University.

1986. Reciprocity in International Relations. International Organization, Cambridge, Mass., v. 40, n. 1, p. 1-27, Winter.

KLEIN, B. S. 1990. How the West was One : Representional Politics of NATO. International
Studies Quarterly, v. 34, n. 3, p. 311-325, Sept.

KRASNER, S. D. 1982. Regimes and the Limits of Realism : Regimes as Autonomous Variables. International Organization, Cambridge, Mass., v. 36, n.2, p. 497-510, Spring.

(ed.). 1983. International Regimes. Ithaca : Cornell University.

MARTINS, L. 1992. A reformulação da ordem internacional. Política Externa, São Paulo, v. 1, n. 1, p. 116-121, jun.

MANDELBAUM, M. 1996. The Reluctance to Intervene. In : ART, R. J. \& JERVIS, R. (eds.). International Politics : Enduring Concepts and Contemporary Issues. New York : Harper Collins College.

MEARSHEIMER, J. J. 1990. Back to the Future : Instability in Europe After the Cold War. International Security, Cambridge, Mass., v. 15 , n. 1, p. 5-56, Summer.

MCCALLA, R. B. 1996. NATO's Persistence After the Cold War. International Organization, Cambridge, Mass., v. 50, n. 3, p. 445-475.

MCGWIRE, M. 2000. Why Did We Bomb Belgrade?. International Affairs, London, v. 76, n. 1, p. 1-23.

MERTUS, J. A. 2004. Bait and Switch. Human Rights and U.S. Foreign Policy. New York : R. Taylor \& Francis.

MESSARI, N. 2003. Segurança no pós-Guerra Fria : o papel das instituições. In : ESTEVES, P. L. (org.). Instituições internacionais : segurança, comércio e integração. Belo Horizonte : PUC-MINAS.

MILLER, B. \& KAGAN, K. 1997. The Great Powers and Regional Conflicts : Eastern Europe and the Balkans from the PostNapoleonic Era to the Post-Cold War Era. International Studies Quarterly, v. 41, n. 1, p. 51-85, Mar.

MIÑóN, M. H. 1999. Kosovo y la nueva estrategia atlántica. Política Exterior, v. XIII, n. 71, p. 55-66, sept.-oct.

MONCADA, H. S. C. 2000. Algumas considerações sobre o conflito do Kosovo no quadro da desintegração da Jugoslávia. Lisboa : Almedina. 
NATO. 1949. Tratado do Atlântico Norte. Brussels : North Atlantic Treatise Organization. Disponível em : http://www.nato.int/ docu/other/po/treaty-po.htm. Acesso em 4.fev.2004.

1991a. The Alliance's Strategic Concept. Brussels : North Atlantic Treatise Organization. Disponível em : http:// www.nato.int/docu/basictxt/b911108a.htm. Acesso em : 4.fev.2004.

1991b. NATO's Core Security Functions in the New Europe. Brussels : North Atlantic Treatise Organization. Disponível em : http:/ /www.nato.int/docu/comm/49-95/ c910607b.htm. Acesso em : 4.fev.2004.

1999. The Alliance's Strategic Concept. Brussels : North Atlantic Treatise Organization. Disponível em : http://www.nato.int/docu/pr/ 1999/p99-065e.htm. Acesso em : 4.fev.2004.

NOGUEIRA, J. P. 2000. A guerra do Kosovo e a desintegração da Iugoslávia : notas sobre a (re)construção do Estado no fim do milênio. Revista Brasileira de Ciências Sociais, São Paulo, v. 15, n. 44, out.

NYE JUNIOR, J. S. 2000. The US and Europe : Continental Drift? International Affairs, London, v. 76, n. 1, p. 51-59.

2002. Compreender os conflitos internacionais : uma introdução à Teoria e à História. Lisboa : Gradiva.

PATRIOTA, A. A. 1998. O Conselho de Segurança após a Guerra do Golfo : a articulação de um novo paradigma de segurança coletiva. Brasília : Instituto Rio Branco.

1999. Sobre um novo democrata. Disponível em : http://143.107.80.37/nupri/ resenhanorte971.htm. Acesso em : 4.fev.2004.

PROENÇA JÚNIOR, D. \& DUARTE, É. 2003. Projeção de poder e intervenção militar pelos Estados Unidos da América. Revista Brasileira de Política Internacional, Brasília, v. 46, n. 1, p. 135-152.

RADOS, M. 1999. Quem matou a Jugoslávia? Porto : Campo das Letras.
RODRIGUES, S. M. 2000. Segurança internacional e direitos humanos. A prática da intervenção humanitária no pós-Guerra Fria. Rio de Janeiro : Renovar.

SARAIVA, M. G. 1999. Os Bálcãs e a construção de uma nova ordem internacional. Carta Internacional, São Paulo, ano VII, n. 73, mar.

SATO, E. 2000. A agenda internacional depois da Guerra Fria : novos temas e novas percepções. Revista Brasileira de Política Internacional, Brasília, ano 43, n. 1, p. 138-169.

SIKKINK, K. 1993. The Power of Principled Ideas : Human Rights Policies in the United States and Western Europe. In : GOLDSTEIN, J. \& KEOHANE, R. O (eds.). Ideas and Foreign Policy : Beliefs, Institutions and Political Change. New York : Cornell University.

SLOAN, S. R. 1995. US Perspective on NATO's Future. International Affairs, London, v. 71, n. 2, p. 217-231, Apr.

SOBEL, R. 1998. Trends : United States Intervention in Bosnia. The Public Opinion Quarterly, v. 62, n. 2, p. 250-278, Summer.

STROMSETH, J. 2003. Rethinking Humanitarian Intervention : the Case for Incremental Change. In : HOLZGREFE, J. L. \& KOEHANE, R. O. (eds.). Humanitarian Intervention. Ethical, Legal, and Political Dilemmas. Cambridge : Cambridge University.

VEIGA, F. 2001. La trampa balcánica. Madrid : G. Mondadori.

VIGGIANO, J. L. 2005. Uma questão de segurança internacional : aspectos do regime de Organização do Tratado do Atlântico Norte (OTAN) na década de 90. Casos Bósnia e Kosovo. São Paulo. Dissertação (Mestrado em Ciência Política). Universidade de São Paulo.

VILLA, R. A. D. 1999. Da Crise do realismo à segurança global multidimensional. São Paulo: Annablume.

WALKER, S. G.; SCHAFER, M. \& YOUNG, M. D. 1999. Presidential Operational Codes and Foreign Policy Conflicts in the Post-Cold War World. The Journal of Conflict Resolution, v. 43, n. 5, p. 610-625, Oct.

WEDGWOOD, R. 1999. NATO's Campaign in Yugoslavia. The American Journal of 
International Law, v. 93, n. 4, p. 828-834, Oct.

WESTENDORP, C. 1999. Kosovo : las lecciones de Bosnia. Política Exterior, v. XIII, n. 70, p. 45-57, jul.-ago.

WESTERN, J. 2004. U.S. Policy and Human Rights in Bosnia. The Transformation of Strategic Interests. In : LIANG-FENTON, D. (ed.). Implementing U.S. Human Rights Policy. Washington : United States Institute of Peace.

WÖRNER, M. 1989. The Alliance. A Key Player in the Future. Address given by Secretary General, Manfred Wörner, at the $35^{\text {th }}$ Annual Assembly of the Atlantic Treaty Association. Brussels : North Atlantic Treatise Organization. Disponível em : http://www.nato.int/docu/ speech/1989/s891026a_e.htm. Acesso em : 28.nov.2004.

1990. The Atlantic Alliance and European Security in the 1990s. Address by Secretary General, Manfred Wörner, to the Bremer
Tabaks Collegium. Brussels : North Atlantic Treatise Organization. Disponível em : http:// www.nato.int/docu/speech/1990/ s900517a e.htm. Acesso em : 28.nov.2004.

WOODWARD, S. L. 1995. Balkan Tragedy. Chaos and Dissolution after the Cold War. Washington : The Brookins Institution.

YOST, D. S. 1998. The New NATO and Collective Security. Survival, London, v. 40, n. 2, p. 135160 , June.

2002. Transatlantic Relations and Peace in Europe. International Affairs, London, v. 78 , n. 2, p. 277-300.

YOUNG, O. R. 1982. Regimes Dynamics : The Rise and Fall of International Regimes. International Organization, Cambridge, Mass., v. 36 , n. 2 , p. $277-297$.

2000. A eficácia das instituições internacionais : alguns casos difíceis e algumas variáveis críticas. In $:$ ROSENAU, J. \& CZEMPIEL, E. -O. (orgs.). Governança sem governo : ordem e transformação na política mundial. Brasília : UNB.

\section{OUTRAS FONTES}

NATO Review. 2002. Inverno. Disponível em : http://www.nato.int/docu/review/2002/issue4/ portuguese/main.htm. Acesso em : 4.dez.2006.
Prague Summit Declaration. 2002. Disponível em : http://www.nato.int/docu/pr/2002/p02127.htm. Acesso em : 4.fev.2004. 